\title{
GORDANA BLAGOJEVIĆ
}

\section{Contemporary composer Vladimir Jovanovic and his role in the renewal of church Byzantine music in Serbia from the 1990s until today}

\begin{abstract}
This work focuses on the role of the composer Vladimir (Vlada) Jovanovic in the renewal of church Byzantine music in Serbia from the 1990s until today. This multi-talented artist worked and created art in his native Belgrade, with creativity that exceeded local frames. This research emphasizes Jovanovićs pedagogical and compositional work in the field of Byzantine music, which mostly took place through his activity in the St. John of Damascus choir in Belgrade. The author analyzes the problems in implementation of modal church Byzantine music, since the first students did not hear it in their surroundings, as well as the responses of the listeners. Special attention is paid to students' narratives, which help us perceive the broad cultural and social impact of Jovanović's creative work.
\end{abstract}

KEYWORDS: composer Vladimir (Vlada) Jovanović, church Byzantine music, modal music, St. John of Damascus choir.

\section{Introduction}

This work was written in commemoration of a contemporary Serbian composer ${ }^{1}$ Vladimir Jovanović (1956-2016) with special reference to his role in the renewal of church Byzantine music in Serbia from the beginning of the 1990 s until today. ${ }^{2}$ In the text we refer to Vladimir Jovanović as Vlada - a shortened form of his name, which relatives, friends, colleagues and students used most often in communication with the composer, as an expression of sincere closeness.

A tendency to search for one's roots, increased interest in tradition, church life and original folk music were present during the 1990 in Serbian society. Special attention is paid to the problems the first students were facing while trying to master the modal music which did not exist in their immediate vocal

${ }^{1}$ To whom are interested in Vladimir Jovanovič’s works see (Milojković, 2017).

${ }^{2}$ This paper is the result of Project no. 177022: National culture of Serbs between the East and the West, by the Ministry of Education, Science and Technological Development of the Republic of Serbia. 
surroundings, the ways of teaching Byzantine music, as well as the choirs and schools of Byzantine music started by Jovanović's students.

As an insider, I had the opportunity to collect material for this work during the years of field research and active participation as a choir member, i.e. female chanter at St. John of Damascus brotherhood since 1992. In addition to many years of 'internship' as a student and a participant, numerous conversations and a targeted scientific interview with the composer Vladimir Jovanović, research methodology also involved many interviews and casual conversations with his students. ${ }^{3}$ I have devoted a number of studies and presentations at scientific meetings in Serbia and abroad to the anthropological issues with Byzantine music in Serbia through the perspective of this choir activity (Blagojević, 2005, 2012, $2014,2015,2017 a, 2017 \mathrm{~b})$. In this paper I will try to highlight the contribution of Vladimir Jovanovic to the renewal of the modal sound through Byzantine chanting in Serbian liturgical corpus. I chose this school as a case-study because it was the first school of Byzantine chanting in secular, i.e. non-monastic environment, which brought forth a series of talented students. It is characteristic that many students had learned the new method from Jovanović and later became teachers and started their own choirs and schools of Byzantine music.

\section{Church Byzantine music among the Serbs - a historical framework}

Byzantine church music is the oldest layer of ecclesiastical music tradition in Serbia and in the Balkans, continuously developing in this region to the present day. Within Serbian music, church Byzantine music represents the oldest written form. The specificity of the Serbian recension of the Church Slavonic language influenced the creative design and adaptation of Byzantine tunes in communicating the textual message (Rajković-Petronijević, 1978, p. 247; Stefanović, 1961a, p. 187; Stefanović, 1961b, pp. 108-110). Church Byzantine music has been nurtured and preserved in the living tradition of the church for centuries. It is modal, has its own rules, a system of music scales and a specific way of recording that has undergone several reforms over time (Státhhs, 2016; Mayroeidhs, 1999; Kavarnos, 1978, p. 86; Blagojević, 2005, p. 156).

The turbulent Serbian history, numerous wars, rebellions and related conflagrations led to the fact that today we have relatively small number of preserved music manuscripts of Serbian medieval recension (Blagojević, 2017a, p. 41). The earliest known manuscripts are from the 15th century. The names of Serbian composers from that period are Isaiah the Serb, kir Stefan the Serb and kir Nikola the Serb (Rajković-Petronijević, 1978, p. 247). In the 18th century there was a school of Byzantine music founded by the Belgrade Metropolitan bishop Mojsije Petrović in Belgrade (Grujić, 1906, p. 23). After the reform of the Byzantine

${ }^{3}$ I would like to thank everyone who participated in this research. Without their willingness to cooperate this work would be much poorer. Due to the limited scope of this paper I was able to present only a small part of the quotations from the interview. 
music notation carried out in 1814 by three teachers (Chrysanthos of Madytos, Gregorios the Protopsaltes, Chourmouzios the Archivist), the new method of Byzantine music did not reach Serbia, mostly due to the unfavorable social and political circumstances. ${ }^{4}$ It was the time of the First and Second Serbian uprising - the struggle for independence from the Turks.

From 1815 in the newly established Principality of Serbia there was a tendency to attach to Western European cultural trends, but there was also an increase in the Russian influence on church life. As a result, in the last quarter of the 19th century polyphonic choirs and singing societies were formed (Perković, 2008, pp. 6-9). The connection with the Byzantine musical tradition was weakening and the new method notation was unknown. During the second half of the 19th and early 2oth centuries, the oral church music tradition was recorded using five line staff, primarily thanks to the dedicated melographic work of Kornelije Stanković (1831-1865), Josif Marinković (1851-1931), and Stevan Stojanović Mokranjac (1856-1914). Thus, Serbian church music has lasted to the present time apart from its original modal form (Perković, 2008, pp. 68-98).The term 'Serbian church music' in Serbia today includes Byzantine music, the newer layer of the so-called Serbian folk church singing and polyphonic choral music, that is, church music written by certain composers (Perković, 2008, p. 5).

\section{Contemporary composer Vladimir Jovanović}

During the 20th century Serbian society was exposed to various social and political changes. After the Second World War Serbia became a part of socialist Yugoslavia. The Orthodox Church was under attack by the new communist ideology, which also affected the development of church art. Revitalization of religious life and increased interest in traditional heritage took place in Serbia during the 1990 and the break-up of Yugoslavia (Blagojević, 2005, p. 163). However, in this period of economic crisis and existential uncertainty, the dominant narrative was the so-called 'turbo-folk'. In response to the deterioration of social and moral norms, some predominantly young people from different social layers found an 'exit' in amateur and semi-professional music engagement. Across the entire Serbia, especially in the city centers, many choirs and singing groups were established and engaged in various types of music, among them church and traditional folk music. It was an expression of the need for belonging and creating new communities. Networking through common cultural activities, primarily through music, i.e. joint singing, gave a sense of security in the darkness of social disintegration. Thus started the building of the community of Byzantine music.

Byzantine singing in liturgical life in Serbia came to life again primarily thanks to the activity of the two monasteries: St. Prohor Pčinjski near Vranje in the south and the Holy Archangels in Kovilj in the north of the country, as

\footnotetext{
${ }^{4}$ For more about the new method of Byzantine music and the work of the three teachers see: Romanou, 1973, 1985, 2010; Státhhs, 2016; Blagojević, 2017.
} 
well as the devoted work of the composer Vladimir Jovanović and a group of his students in Belgrade (Blagojević, 2005, pp. 164-165; Blagojević, 2017a, p. 42).

Vladimir Vlada Jovanović became active in the field of church music in the spirit of seeking spiritual identity, which was pervasive in one part of Serbian society in the early 1990s, as I said before. He was born in the mid-fifties of the last century in Belgrade, where he lived and worked. Through his artistic work, he expressed various aspects of the global and local cultural trends in which he actively participated. He was a composer, a devotee in the field of Byzantine church music as a teacher, chanter and protopsaltis. In a work published in co-authorship with Aleksandra Pavićević, we studied in detail Jovanović's biography, his work in the field of electroacoustic music and the relationship between artists and the epoch in which they acted, therefore here I will only provide some basic information (Pavićević, Blagojević, 2018). Milan Milojković gave a detailed analysis of Jovanović's opus of electroacoustic music (Milojković 2017, pp. 79-96).

After graduating from high school in Belgrade, Vlada Jovanović enrolled at the Faculty of Philosophy where he studied philosophy for two years. However, the need to express himself through music prevailed. He enrolled at the Faculty of Music, although he did not complete secondary music school. After successfully completing his studies, he started composing. During the second half of the 1980 s he was a member of an informal group of contemporary composers, The Magnificent 7 (Kovač, 1991, p. 43; Milin, 2008, p. 8, p. 94; Milojković, 2017, pp. 84-85; Pavićević, Blagojević, 2018, pp. 331-333).

For the most part of his career he dealt with electro-acoustic music and radiophonic projects.His colleagues from Radio Belgrade's Third Program describe him as an 'unusual artist, an author with great creative power, an expert in contemporary electronic as well as spiritual music' (Savremena srpska muzika - Vladimir Jovanović, 2016). From 2002 he directed the Electronic Studio of Radio Belgrade's Third Program. He was the editor of the unique program cycle dedicated to the Holy Mountain chanting tradition, broadcast from November 2006 to March 2008 under the title Mount Athos Chant Tradition on Radio Belgrade's Third Program (Pavićević, Blagojević, 2018, p. 339).

His compositions were performed at festivals in Serbia, France, Germany and Italy. ${ }^{5}$ A compact disc with some of the works was released in 2018 by the Vertical Jazz label, called Bellscapes, electroacoustic music by Vladimir Lj. Jovanović. ${ }^{6}$

We see the freedom of Jovanovic's creative spirit that allowed him to move equally with ease among contemporary artists and in monastic circles on Mt. Athos.On the Third program of Radio Belgrade he simultaneously affirmed and made accessible electroacoustic music and Mt. Athos chanting skills and experience to those who 'have ears to hear': open-minded listeners, thirsty for true artistic and spiritual content.

${ }^{5}$ A detailed list of compositions can be found in: Milojković 2017, pp. 79-96 and Pavićević, Blagojević, 2018, pp. 331-333.

${ }^{6}$ With compositions: Pilgrimage to the Gardens of Emptiness. Electro-acustic metamorphoses - triptych, Bellscapes. Four electro-acoustic scenes (in memory of Pierre Schaeffer), Aah Beeah E Doo Aah (Electro-acoustic Tee Teh Teh Pooh Ph). 
The artist's appearance was in harmony with his work. Vlada Jovanović distinguished himself by a characteristic combination of contemporary urban style and Orthodox spirituality: a long beard, his hair tied in a ponytail, casual clothes, jeans, and an inevitable cigarette in his hand.

Jovanović began studying notation of Byzantine music in 1988 with protodeacon Dragan Ašković, a theology student at that time and currently professor of church music at the Belgrade Theological Faculty (Blagojević, 2017a, p. 45; Pavićević, Blagojević, 2018, p. 334). Then he deepened his knowledge of Byzantine chanting at the Holy Mountain, at the Hilandar monastery with the hegumen Pajsije Hilandarac (who later became the hegumen of the Prohor Pčinjski monastery near Vranje) and a Gregorian monastery. The ethos of the Mount Athos chant would remain the main model in Jovanović's later work.

He became a member of the Iconographic - chanting brotherhood of St. John of Damascus, founded in 1989 in Belgrade (Blagojević, 2011, p. 224; Mitrović, 2014, p. 91; Pavićevič, Blagojević, 2018, p. 334). Already in 1990 he started singing in the Belgrade monastery Vavedenje (The Entrance of the Theotokos) with two more chanters (Pavićević, Blagojević, 2018, p. 335).

\section{Work in the Belgrade choir St. John of Damascus}

Vladimir Jovanović began giving chanting lessons in Belgrade in 1990, with the blessing of Metropolitan bishop Amfilohije Radović, Bishop of Banat at that time.The largest group of students started in October of 1992. The classes were held in the old building of the Orthodox Theological Faculty and in the parochial building of the church of St. Alexander Nevsky. Teaching and rehearsals of the choir were held as needed in the home of Vladimir Jovanovic and also Predrag Stojković, who is today hieromonk Lazar, hegumen in the Zagrađa monastery in Montenegro. Father Lazar, as a student and an associate, was a great support to Jovanović in the choir. Stojković inspired with his natural charisma and as a multitalented artist (painter, icon and fresco painter, musician, protopsaltis, instrument maker, guitar, kaval and flute player) multiplied his gifts by encouraging with his example all those who came in contact with him.

In 1993 the church Byzantine choir St. John of Damascus was founded in Belgrade. It was made up of Jovanović's students and consisted of male and female groups of singers. Vlada Jovanović taught all the lessons and led choir rehearsals devotedly, absolutely free of charge. In the beginning, the choir was singing by invitation in various Belgrade parish churches. It finally settled in two places, so that the choir participated in church services in the churches of Alexander Nevsky (from 1993 to 2001) and Holy Apostles Peter and Paul (from 1993 to 2001, and with reduced frequency to the present).

Interestingly, in the memorial of the St. Alexander Nevsky Temple in Belgrade, there is no mention of St. John of Damascus choir anywhere, although the other choirs of that temple are mentioned (Arsenijević, 2015).

It was the first school and the first kind of workshop of Byzantine chanting in secular, non-monastic conditions in Serbia and it produced a number of talented 
students. ${ }^{7}$ Many of the trainees of various profiles (philologists, musicians, painters, icon painters, architects, theologians, mathematicians, ethnologists, chemists, ethnomusicologists etc.) have passed through this school (Blagojević, 2005, p. 166).

In addition to active members of the choir, there was an informal group of mostly young people of both sexes, a kind of 'fan club'. They, as people of faith, actively participated in the worship services where the choir sang. After the Liturgy, it was common for everyone to sit in a parochial building for agape, modest refreshment that included tea, coffee and pastries. During conversations with choir members and Jovanović, they spontaneously commented and talked about their impressions of chanting, which to some extent affected the work of the choir.

The question is: what are the motives for acquiring this kind of knowledge? What attracted those people to learn Byzantine chanting from some 'strange' notes, how did they perceive it, and was their involvement with this music only a brief enthusiasm or long-standing preoccupation? It should be emphasized that the social status of the chanter in Greece and in Serbia is very different. ${ }^{8}$ During the nineties Jovanović organized a large number of initial groups and some of his students later continued to deepen their knowledge, practicing in church services.

At the initial level, the teaching implied the adoption of a specific semiography, neume notation according to the new method - the contemporary so-called Chrysanthos notation of Byzantine church music. ${ }^{9}$ The book Theory of Byzantine Church Music by Ioannis Margaziotis was used in the lessons (Margaziotis, 1958). After being trained to read the music, students learned first the liturgy of St. John Chrysostom (in the first tone) and then other church songs.

The majority of candidates did not have formal music education. This, on the one hand, made it easier, but on the other made it difficult for the teacher to work. The notes of Byzantine music were the first notes they mastered. The teacher did not allow them to record him singing exercises and songs. The material was adopted on the basis of neume recording, listening in the class and musical memory. This is in contrast to the newer method used in Greek schools of Byzantine music, where students are obliged to record a teacher. Vlada wanted to consistently follow and apply the traditional way, because the ability to record and play through the sound carriers is a supplementary resource of a relatively new date.

However, thanks to the team work, enthusiasm and joy of learning, notation was mastered in an incredibly short time of two months! Vlada Jovanović

7 I touched on the issues of adopting modal sound and the so-called 'new method' notation of Byzantine music by Vladimir Jovanović's students within the music workshop of Byzantine chanting and ther St. John of Damascus choir from 1990 to the beginning of 2000 in my paper 'New method' of Byzantine music in chanting practice of Serbian Orthodox church from the end of 2oth century to the present in the light of cognitive anthropology, which I presented in 2015 at the conference in Athens. That was during the composer's lifetime and I discussed it with him personally.

${ }^{8}$ More on the social status of church singers in Serbia and Greece in: Blagojević, 2014, 145-147.

${ }^{9}$ More about Chrysanthos' notation and system of recording of Byzantine church music in: Konstantinu, 2014; Státhhs, 2016, 181-192; Blagojević, 2017b, pp. 25-31. 
refused no one who wanted to learn to sing and he believed that everyone could sing with enough practice and effort. He had a group of students who studied the distinction between basic intervals, for example 'ni-pa' (!). In 1814, based on solfeggio in Western European music, the new method of Byzantine music introduced: monosyllabic names for the tones of the scale: ni, pa, vu, ga, di, ke, zo, ni (Karás, 1982, p. 2; Státhhs, 2016). These, until then unfamiliar terms in Belgrade, created confusion and encouraged imagination to make up stories, namely urban narratives about people dealing with Byzantine music, in the jargon of church circles known as byzantines. ${ }^{10}$ In my earlier work I mentioned that this even led to the conclusion that it was some sect, whose members were engaged in mantring. Those unusual mantras were, in fact, the names of the tones (Blagojević 2005, p. 167).

Work in this group can be viewed as a type of unprogrammed social experiment. Namely, we can observe and analyze how a group of people master the basics of Byzantine chanting, what their reactions are during the learning process and the reactions of the environment. This group was characterized by 'sound isolation', conditionally speaking, because at the time when the firstgroup of students started learning Byzantine music notation, this kind of chanting was impossible to hear 'live' anywhere in Belgrade. There was no internet at that time; the only source of knowledge was the teacher - his voice and the audio recordings he gave us. In addition, there was no other kind of modal music sounding in the surroundings. Moreover, a large number of the first students had never heard this music at all, except a few who heard it live in Greece.

Thus, the two students, who later became founders of new Byzantine choirs, Natalija Mijatović and Jelena Stojaković (married name Smiljanić) first heard this chant in the early nineties, at the festival of choirs in Kardica (Greece) where they performed with the First Belgrade Singing Society under the direction of Divna Ljubojević. ${ }^{11}$ Natalija Mijatović says about her first encounter with the Byzantine chant: '...a Greek male choir performed. As they sang, a wave of deep, ancient beauty and truth crushed over me, and tears ran unbridled down my face. The wave directly from the wellspring, deep in my being. I have never heard this chant before, but at that moment I recognized that I belong to that sound and that it carries my spiritual heritage. When we returned home, my friend from the choir and I embarked on a quest to find someone who knew this chant. On a church door somewhere, we saw a flyer about Byzantine chant choir, signed by Vlada Jovanović. And that's how it all started. We found ourselves in the first group of seekers, to which you and your sister belong, and the many of our beautiful and beloved singers. I then left Divna's choir, ${ }^{12}$ completely surrendering to the newly-established choir of St. John of Damascus'.

Vlada Jovanović used to give his students audio recordings of different chanters and choirs, cassettes with samples based on tones of Byzantine music

${ }^{10}$ This informal name was given to the group of people in relation to the type of music they deal with, and not the historical period. In analogy with rock music and rockers, heavy metal and metalheads, punk and punks, those who deal with Byzantine music have become byzantines, so this is why the name is written with a small letter 'b'.

${ }^{11}$ See more about Divna Ljubojević in: Blagojević, 2012, pp. 182-184.

${ }^{12}$ Divna Ljubojević' choir Melodi. 
so they could hear the intervals. The main models were the Holy Mountain singers, hierodeacon father Dionysios Firfiris, brotherhood Danileyi from Katounakia, brotherhood Spiridon and Tomaida from the Little St. Anna Skete and many more. At that time none of us knew about the divisions among Greek chanters and different styles. The criterion to choose and listen to something was audio experience, not a 'pre-knowledge'.

Based on soundtrack listening, students themselves noticed that there were great differences in chanting between various Greek choirs and chanters. In addition, after long-term listening, it became apparent to them that there were deviations between written music and the music that one could hear in the chant. Namely, some choirs and chanters sang only the notation structure, without analysis.

During lessons, Vlada used to sing neume notation in various possible ways i.e. the different energies of character ${ }^{13}$ Students called those analyses 'decorations' and this term is still in use today among chanters. In order to synchronize chanting, as analyses typically were not written, students used to make their own signs in the places where they were supposed to sing them. Each student had his own recording system but some signs everyone recorded the same way, for example little hook, little umbrella, circle, etc. The form of the signs for the analysis depended on the personal feeling of the student, the way a person visually articulates the movement of the voice. These personal signs recorded by the students served only as a reminder of a musical phrase they memorized through an oral tradition. Thus, unconsciously they used the same synoptic principle that had been in use in Byzantine music before the introduction of the new method in $1814 .{ }^{14}$

Byzantine music is unison. However, characteristic for this type of chanting is the presence of ison, i.e. a kind of bordun - singing one even tone. As there are different interpretations in the singing of the basic melody, in practice there are also different approaches to singing ison among Greek chanters. In some schools they practice frequent changes in accordance with the logic of harmonization of Western music. Then, some pronounce words from the melody while keeping that particular tone, and others sing only a neutral syllable. In the end, Jovanović decided to practice one tone, the basis of the voice in neutral syllable. However, there was opposition in the women's choir because it was monotonous, so they wanted to pronounce words and sometimes harmonize the melody.

Some of the students, although gifted chanters, decided to sing ison from the beginning, as Natalija Mijatović:

Although I sang the leading melodic lines of the soprano for years, I immediately felt a strong calling for chanting ison. I am deeply convinced that the gift that the Lord generously bestows upon us has found us, and not us, him. It is wonderful to sing, but to sing ison is a particularly profound experience of unity and service to others. You cast your voice into the foundation of the melody, as roots from which the tree grows to its heights, towards eternity. Dense canopy and flowers are a melody that ascend our prayer to the heights with its beauty and scent, and ison,

${ }^{13}$ See more about the different ways of interpreting neume notations of the new method in: Konstantinu, 2014.

${ }^{14}$ More on the synoptic way of recording of Byzantine music in: Státhhs, 2016, pp. 78-108; Blagojević, 2017b, pp. 25-29. 
restrained and unwavering, sensibly provides strength from the depths of our tradition, connecting the past and the future into eternity. For me ison is a thundering silence.

Vlada had a spiritual, mystical approach. He emphasized to his students the need for inner spirituality. He spoke of chanting as a means to achieve blessing. Choir rehearsals always began with a prayer he composed and ended singing a troparion to St. John of Damascus. Jovanović used to begin lessons and choir rehearsals with a Prayer before chanting, and complete them with Prayer after chanting, which he created himself. Members of the choir St. John of Damascus shared these prayers with friends from other church choirs, so over time prayers entered general use. As anonymous prayers they are available on various Orthodox portals on the internet (Molitva pre i posle pojanja 2018).

He was against performing concerts. Respecting freedom of choice, he did not stop his students from participation in concerts, although he opposed it. He would say: 'How is it possible to sing We praise Thee, a song chanted during liturgy when Holy Gifts are being consecrated, and people applaud you and celebrate your vocal abilities? It is complete nonsense.' On the other hand, Byzantine chanting was a 'forgotten sound' in Serbia, so concert activity had a missionary dimension to some extent.

In the spirit of missionary work, female singers published a cassette Rejoice Mother of God, Most Pure Most Spotless Ladder to Heaven in 1998, and a CD and a cassette Sing to the Lord the new song - psalms of David in 2002 (Blagojević, 2005).

\section{Adaptations and compositions of worship songs}

In the domain of church Byzantine music Jovanović left behind a large number of tunes of liturgical songs, adapting compositions of Byzantine music from printed Greek music editions to Church Slavonic text.

In the beginning, Jovanovic used Bulgarian editions of Byzantine chants collection in the Church Slavonic language. However, he was not pleased with the way music phrases were paired with the text, so he started tailoring them himself. The process of tailoring assumes adapting liturgical text, in this case in the Church Slavonic language, to the phrases of Byzantine music. This project is not easy at all and it requires skill and knowledge, because its aim is to preserve the existing melody line as much as possible and to convey the chanted message clearly. The problem is that the words in the Greek and Church Slavonic languages have a different number of syllables, so creative skills are necessary.

He collected translations in a handwritten manuscript under the title Anthology - week day and feast day singing at Holy Divine Liturgy in eight tones, in the manner of singing on the Holy Mountain of Athos. To Vlada Jovanović, the role model for Byzantine chanting and, in an inseparable relation with that, for spiritual life, was the Holy Mountain tradition (Pavićević, Blagojević, 2018, p. 337).

As a source and inspiration among other things, Jovanovic used the collections of protopsaltis monk Nektarios, an elder in the Great Lavra of St. Athanasios 
the Athonite (Nektarioy monachoviiropsáltoy, 1931). In the beginning, the choir chanted using the photocopied material from that book, into which Jovanović wrote the text in the Church Slavonic language. A good example is the Saturday communion song to the departed Blessed are they whom Thou hast chosen and taken, o Lord. Academician Dimitrije Stefanović described this phenomenon shortly after it took place, concluding that 'Greek melodies have been successfully matched to the Church Slavonic text of Russian redaction, and the way they are performed is very close to the present Greek holy chanting.' (Stefanović, 1994, p. 28).

Vlada Jovanović unselfishly shared his knowledge. He did not charge for his Collection and he did not have any material benefit from this work. With his permission, students were making copies of the Collection.

He gave his students a handwritten Anthology of 480 pages where there are liturgies of St. Apostle James, St. Basil the Great, St. John Chrysostom in eight tones, the liturgy of Pre-sanctified gifts, then feast and week day antiphons, As many as have been baptized into Christ, To Thy Cross, irmoses instead of It is truly meet to bless you, Sunday and feast day communion hymns, the Paschal canon and the entire matins service, Psalms 1 (plagal of 4th tone), 5 (4th tone), 23 (3rd tone) (plagal of 4th tone), 135; Songs to Virgin Mary, $O$ Virgin Pure, i.e. Agni Parthene, the song of St. Nectarios of Aegina, adapted to the Church Slavonic language (Agni Parthene Despina 2017) and Do not entrust me to human advocacy, Paschal, weekday, feast day troparions and kontakions, as well as troparions and kontakions of the Penticostar and generally to the Saints; beatitudes in eight tones, Paschal and weekday prokimenons, Alleluia in all tones, from the Book of needs: the order of blessing and cutting of kolach, the wedding and baptism services.

The anthology came off the press in 2017 in the form of a facsimile, handwritten by the author, as it is also sometimes the case in Greece - for example, editions of the Greek chants teacher Simon Karas..$^{15}$ The last author's redaction of the Anthology was completed in March 2001. The volume consists of 285 pages, as the troparia and kontakia from the previous editions were omitted. The Anthology was printed thanks to the commitment of the choir members and friends, true admirers of his work, with the financial aid from the servants of the Holy Resurrection of Christ church in Vienna (Pavićević, Blagojević, 2018, p. 337). The previously mentioned Jovanović's prayers before and after chanting are also published in the Anthology. Jovanović also incorporated the Greek edition of Octoechos into the Church Slavonic language and it is also in the manuscript.

Jovanovićs collection of Byzantine ecclesiastical singing was gathered over the years through live interaction with students. He used to bring draft versions to rehearsals where students would sing them and he would correct certain places during the performance. He corrected many songs, especially from the liturgy of St. John the Chrysostom, years later. Adjusting to the new version required patience from the students who knew the previous version by heart. Jovanović, as a true artist, strived for continuous improvement. So, songs in the current Collection represent the fourth or fifth edition (Pavićević, Blagojević, 2018, p. 337).

${ }^{15}$ See for example: Karás, 1982. 
Waronz वे

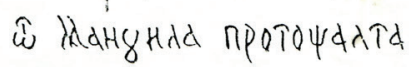

Tतब'ंट् $\ddot{H}$ o

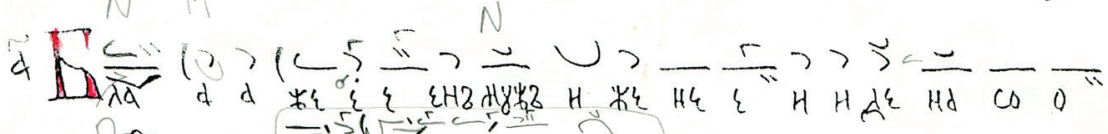

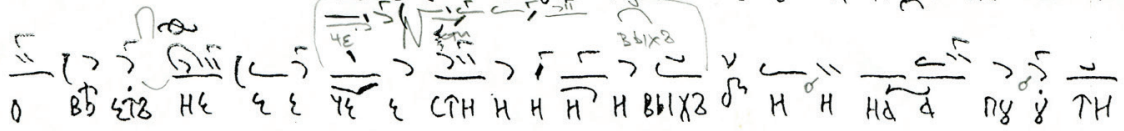

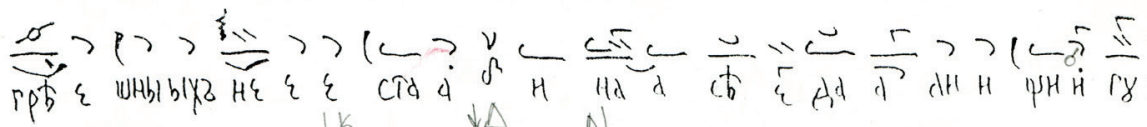

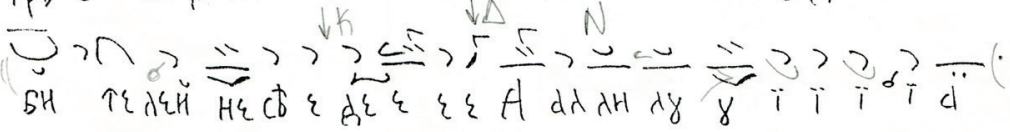

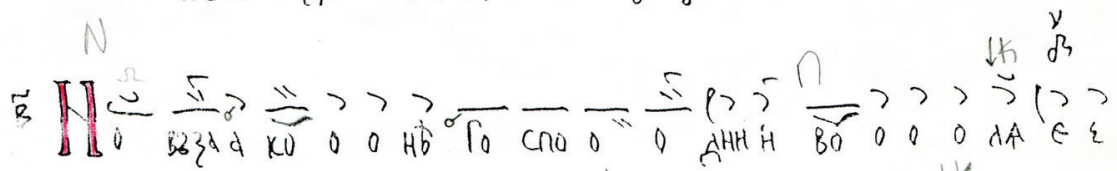

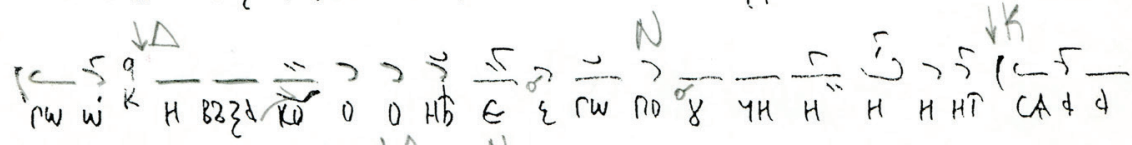

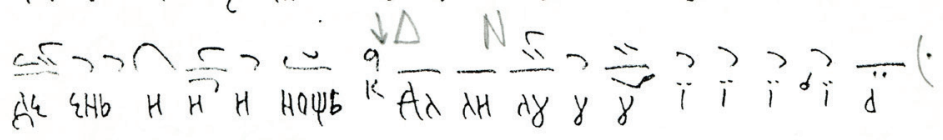

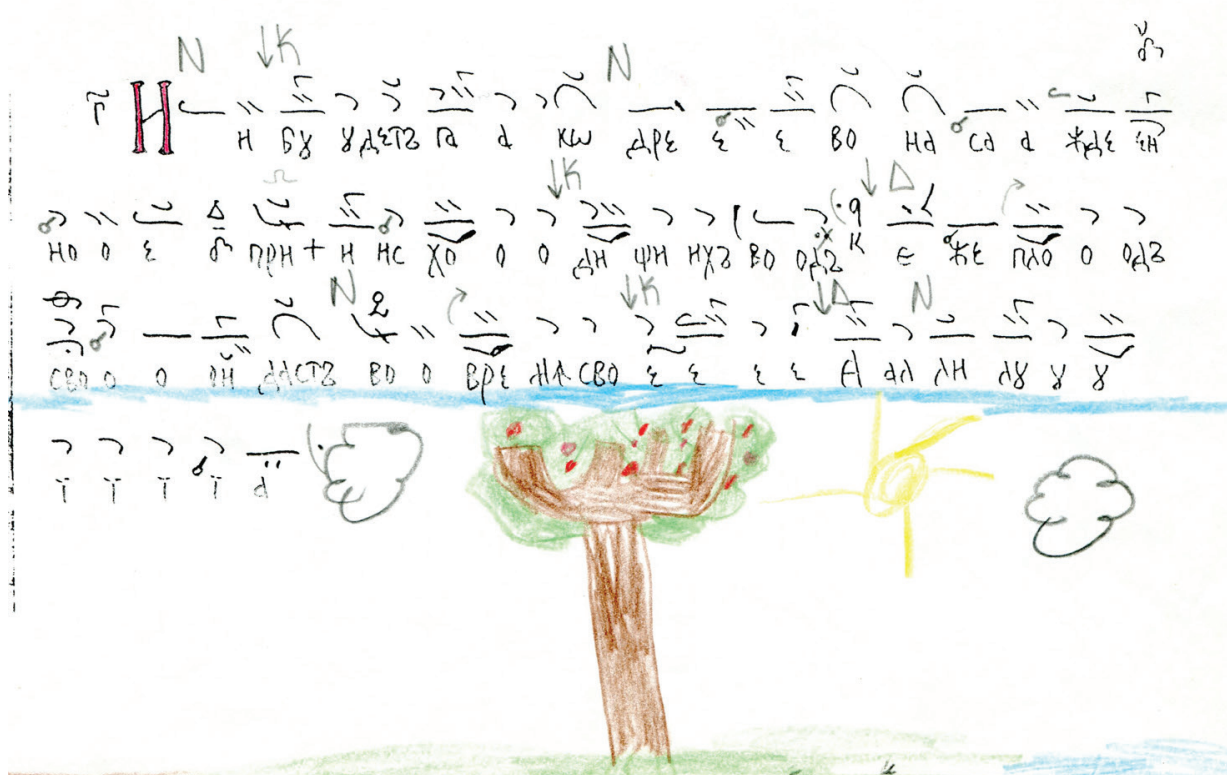




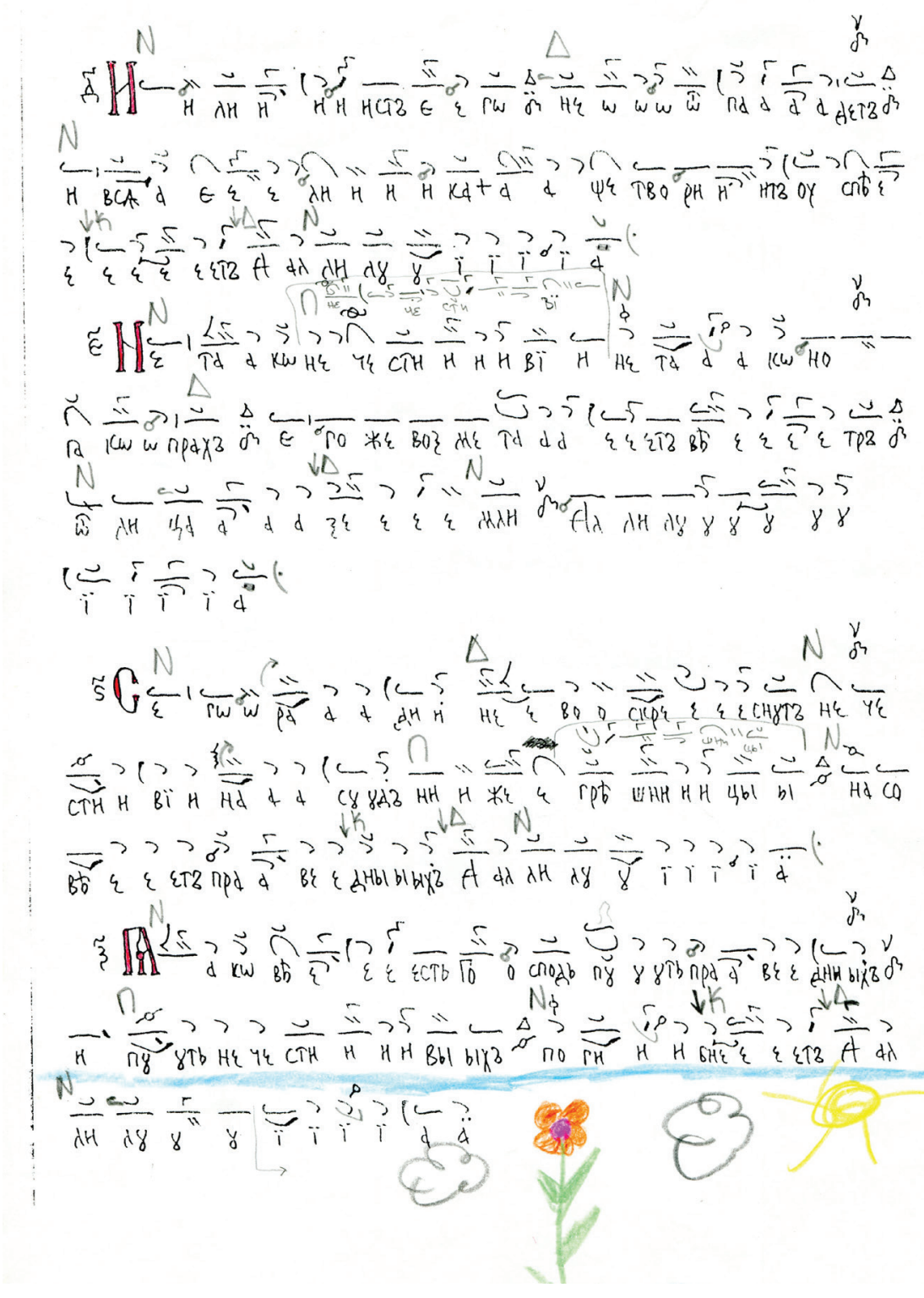

Fig. 1. The first psalm with the drawing by composer's daughter, Smiljana Jovanović. She made the drawing after I asked her, at one of the rehearsals she attended as a little girl.

There are disagreements regarding the accenting of Church Slavonic text during worship in Serbian Orthodox Church. Opinions are divided, so some think the accents should be in accordance with spoken language in order to be clear to the faithful. However, in different parts of Serbia the accents are different, so for the citizens of central, southern and eastern Serbia the official accents are 
more foreign than the Church Slavonic accents. Jovanovic modified the original Byzantine chanting in order to actually follow the accents of the Church Slavonic text.

It should be noted that the first versions of worship songs, as well as the Liturgy, were chanted using the accents of the modern Serbian language. However, soon he switched to Church Slavonic accents, partly influenced by the teachings of bishop of Budimlje Danilo Krstic of blessed repose (1927-2002), whom he highly respected. Namely, bishop Danilo emphasized that in every developed language system one can see three linguistic levels, which he named marketplace, culture and cult. Consequently, every level has its laws; therefore, Church Slavonic as the cult language of the Serbs has its rules and accents to be respected (Danilo Krstić episkop, 1996, p. 165).

\section{The response to the chanting of the St. John of Damascus choir and Jovanović's work}

Concerning Byzantine chanting from the perspective of the message recipient, the faithful and the clergy, there were various types of problems (Blagojević, 2005; Pavićević, Blagojević, 2018, pp. 337-338). One part of the Belgrade clergy of poorer education resisted, and still does, the modal sound especially those who came as refugees from Bosnia and Croatia. They typically associate the intervals of hard chromatic scale with Turkish and Arabic music. ${ }^{16}$ It is especially difficult to listen to the echos Varis from lower zo tone (Konstantinu, 2014, pp. 174-180). The majority associates this notation with the Arabic alphabet. The sound reminds them of Muslims and mosques, so they forbid its performance at the service, falling into the trap of ethnophiletism and saying that 'we have our Serbian way' and this is something 'foreign, Greek and sounds like Muslim'. On the other hand, the faithful people of different age groups regularly approached the choir to express their enthusiasm, stating that 'this is how they chanted at the time of St. Sava!' (Pavićević, Blagojević, 2018, p. 337). In one of my previous works I devoted a lot of attention to the problems regarding the reception of Byzantine music in the territory of Belgrade-Karlovci Metropolitanate at the end of the 2oth century, so I will not pursue that subject here. I will only point out that it has caused very opposed emotions, from enthusiasm to rejection. By the end of 2001 the St. John of Damascus choir received verbal recommendation from patriarch Pavle to 'sing some of Byzantine chants occasionally' (Blagojević, 2005, p. 167). However, since the activity of the choir was tied to the performance of Jovanovićs creations, this prohibition meant that his compositions could not be performed in the territory of Belgrade-Karlovci Metropolitanate. Church repertoire mostly depends on the personal taste of the appointed bishop and clergy, mainly the church presbyter. Thus, in this case the choir was able to continue to sing when visiting other Metropolitanates (for example, Zahumlje and Herzegovina, Montenegro and the Littoral, Braničevo, etc.). At the same time in Belgrade they freely sang Byzantine chants at the

\footnotetext{
${ }^{16}$ About the features of these musical scales more in: Konstantinu, 2014, pp. 209-215, 228.
} 
Faculty of Theology (Blagojević, 2005, p. 168). However, marginalization and misunderstanding by the clergy damaged Jovanović's health.

In the era of strong ethnic insecurity, i.e. shaken identities, nationalistic and ethno-phyletic rhetoric was mixed with the fear of novelties, so even the thousand-year-old tradition of Byzantine music was perceived almost like avant-garde. Along with this esoteric search for an ethnic identity by the clergy, the ordinary people were openheartedly, instinctively discovering an old St. Sava-like music identity layer.

\section{The students of Vlada Jovanović}

Vlada always emphasized that he 'does not teach this chanting because it is Byzantine, but because it is traditional church music and if he finds another one that better reflects the truth of our Orthodox faith, he will take it'. For him and some of his students the criterion for dealing with this kind of music was not national - because it is 'our national' - nor was it chosen as a 'romantic antiquity'. It was mystical functionality, the desire to testify through the music to God's presence in the world and to reach the other side.

Observing from the time distance, we can clearly see that Jovanovic was a light in an era characterized by a struggle for retention of power or conquering it. Such a social climate was completely in contradiction with this artist, who did not want to rule anyone. He viewed the people who came to him to learn chanting as associates, not subordinate disciples. For Jovanović, the disciples were companions in the quest for the best possible way of praising God. This relationship and attitude was, in most cases, mutual, the students honored him honestly:

I respected and loved Vlada, immensely, i.e. I revered him. I felt admiration for a teacher who so generously and joyfully shared his great gift, and who always felt the responsibility of multiplying what was given to him. I always likened Vlada's presence with the phrase I crafted: Quiet

Thunder (I do not know whether this makes sense linguistically, but see the above for ison). ${ }^{17}$

However, some of the male students, under the influence of the patriarchal narrative, were looking for a dominant leader that would also strengthen their identity in the world, changing at a rapid pace. Thus, some of the students created their own choirs, following the line of narratives thirsty for recognition and success in concert halls and festivals.

Through his work in the field of Byzantine music, Jovanović again finds a long-lost narrative thread of church music. These lessons of Byzantine music, work with the choir, and chanting at church served as a comfort to those who endured various types of decay in daily life (society, economy, disintegration of the country, war danger, etc.). For some of the youth in Belgrade during the $1990 \mathrm{~s}$ Byzantine music was the Ariadne's thread for the escape from the labyrinth of the crisis that continues to our day. This is supported by the words of one of his students: 'I only survived the 1990 os thanks to him. He opened the door I had not York.

${ }^{17}$ Natalija Mijatović, painting professor and art department chair, Binghamton University, New 
seen before and brought me into a parallel world where you can breathe, rejoice and feel needed. We all felt that we were needed, that our efforts made sense. I learned from him to accept and love all people. I learned to keep trying to do my best, to look forward and not to be afraid, especially when I left for the USA. Our rehearsals and friendship have literally given me the strength to rejoice every new day, although it was ' 92, ' 93, ' $94 \ldots{ }^{18}$

Jovanovic started discovering and learning 'new' music quietly, without much noise and advertisements, but the fruits of his labor expanded beyond the Belgrade area. There were many students from other cities in Serbia, Montenegro, Bosnia and Herzegovina, who could then transfer the knowledge to their home environments. Many students became priests as well as monks and nuns who continued to nurture the acquired knowledge according to their abilities in the communities far from Belgrade. Some of the students emigrated to European and overseas countries and continued to cultivate Byzantine chanting there.

Many members of the choir have discovered life in the Church in this community. Characteristic of this, so to speak, movement was the romantic inspiration, the search for the virtue and early Christian life principles. Members of the choir and those who 'followed' and listened to them attempted practising readings from the holy fathers' literature. Among other things, that meant working on a personal level, as well as on the renewal of liturgical life, more often approaching the holy mystery of the communion, which at that time often faced misunderstanding by one part of the priesthood who had learned to give the communion to the people four times a year. Jovanović believed in the transforming power of music. ${ }^{19}$ Vlada adopted this ancient Greek teaching, later the holy fathers' teaching, also known to other nations, and passed it on to his disciples.

According to Radmila Luketić: ${ }^{20}$ 'I hold on to the impression Vlada Jovanović made on me since the Transfiguration in 1993. At that Liturgy, in the church of St. Alexander Nevsky I heard how Heaven sounds and how God comes to be glorified by chanting. Vlada was a rare example of honesty, kindness, godliness, and sincere uncovetousness. Silent, but firm in faith. I knew that I was in the right place at the right time at rehearsals and singing in the church. The most important knowledge of Liturgy, of meekness, of the Kingdom of God, of the Living God, of the God given to us now, who is calling us now, I learned in the kliros of St. John of Damascus, that is, with Vlada Jovanović'.

Some of the students were interested in the restoration of traditional folk music of modal sound and the creation of folk instruments, especially woodwind instruments (Jovanović, 2012).

Besides, a number of choir members showed an interest in the renewal and practice of old crafts, for example artistic book binding (Aleksandar Ćeklić), weaving on the loom (Jelena Dabić), etc. Some of the artists also focused on church art, such as Marina Romanović (now nun Vera) who was already a

\footnotetext{
${ }_{18}$ Tatjana Milovanović, M.Sc. in molecular biology.

19 See Jovanović's interview: Jovanović, 2001.

${ }^{20}$ Radmila Luketić, icon painter, art historian and conservator from Belgrade.
} 
ceramic artist but began to paint icons and make them in the original way in ceramics.

Dragoslav Pavle Aksentijević, Serbian painter and famous interpreter of church and traditional folk music, during the eighties first started chanting in Serbia according to the transcription from the old Byzantine notation in music staff system. According to the records of academician Dimitrije Stefanovic and his own scripts relaying live verbal tradition, also later, already as a renowned interpreter of the church music, he learned notation from Jovanovic in order to complete his theoretical knowledge (Blagojević, 2012, p. 182).

Jovanović taught the new method to many students who would later become teachers themselves, like hierodeacon father Jerotej (Petrović) from the monastery of Holy Archangels in Kovilj, founder of the School of church singing with the same name, St. John of Damascus in Novi Sad (2011), and Nikola Popmihajlov, founder of the choir 'Mojsije Petrovic' (1996) and chanting teacher from Belgrade.

Natalija Mijatovic is the founder of the choir Saint hieromonk Makarios in Cetinje (Montenegro), which she led from 1993 to 1997, during her studies at the Cetinje Academy of Arts:

\footnotetext{
Vlada's quiet thunder, like an avalanche, befell our cultural-religious-geographic landscape. And wherever God's provenance would send the singer from our choir, a new choir would take form. Vlada's gift truly multiplied. I found myself in Cetinje, at the Academy of Fine Arts, and there I formed The Saint hieromonk Makarios. Our Belgrade singers often visited me and we traversed Montenegro, performed in concerts and churches, and left a sister or two behind, in Montenegrin monasteries. And so we did in Serbia. The power of the family bond with my choir meant everything to me. Although I was studying far away, I would occasionally and suddenly appear at the crack of dawn, in the dead of winter, in the side aisles of the church in Nevsky and later in Topčider, right in time for the Liturgy. As if I never left. Even today, when I come from America, I go straight to the choir apse. And I pick up exactly where I left it the last time around. ${ }^{21}$
}

We will mention here only some members of the choir, who chose monastic life and continued to nurture and improve chanting in the monastery centers, for example nun Pajsija from the monastery St. Stefan near Vranje, the already mentioned hieromonk Lazar (Stojković), hegumen in the Zagrađa monastery in Montenegro, hegumeness Amfilohija from the Šudikova monastery near Berane and nun Vera from the Župa convent near Nikšić.

During 2004 and 2005, with the blessing of their spiritual father Nikolaj, a group of five girls attended Jovanović's classes. They were still living in the world at the time but they wanted to become nuns and to foster Byzantine chant in their monastic family. They had lessons several times a week for several hours. One of the students says that every departure to these classes was a holiday for them, and the meeting with Jovanovic left an important positive mark on their lives. Some of these students are now in the monastery of St. Apostle Thomas at Svilajnac. Protopsaltis, Sister Sergia, says that they continued professional contact with the teacher even after going to the monastery. In the monastery, they regularly perform the Liturgy of St. John Chrysostom in the first tone, the

${ }^{21}$ Natalija Mijatović, painting professor and art department chair, Binghamton University, New York. 
Byzantine way that Jovanović translated and integrated into a composition. Due to the great responsibilities of monastic life, in accordance with their possibilities, they gradually continue to master Byzantine melodies, singing certain songs from other worships, such as the Lord I call unto Thee, individual verses, dogmatics, irmoses, etc.

Indiaspora, Tatjana Milovanović led the church singers group in the parish of The Nativity of the Most Holy Theotokos in Orange County (California) from 1998 to 2005, Jelena Smiljanić, was the founder of the female Byzantine singers group at the Serbian Orthodox church of the Holy Resurrection of Christ in Vienna (2016). The signatory of these lines as Jovanović's student continued her training in Greece, and from 2009 to this day she sings Byzanine chants with two more chanters ${ }^{22}$ in the chapel of St. John the Chrysostom at Student city.

Some students who contributed to the field of traditional folk music took inspiration for their work from Byzantine music and their engagement in the St. John of Damascus choir, such as, for example, Vladimir Simić, founder and leader of the group Beloplatno (White Linnen) (Blagojević, 2012, pp. 189-190). Many members of the female singing group Moba met at the St. John of Damascus choir.

According to the students' testimony, chanting, life and work in the St. John of Damascus choir was much more than 'just' singing. Having Jovanović's commitment to work as an example, this has also affected their attitude towards life and work: 'I often think of Vlada, and like every good student, I strive to justify his stake in me. My role in life is ison. I endeavor to provide my children with this constant support that keeps them from within so as not to 'fall in intonation'. I am their root, and my aspiration is for my sons to grow into tall Serbian oaks, albeit on the foreign soil, but with their roots interconnected in the unbreakable network of their ancestors. I have the same approach in teaching'. ${ }^{23}$

\section{Conclusion}

Vladimir Jovanović was concerned with the inner prayerful life, so dealing with music for him was the path to personal transformation and search for the meaning of existence. This multi-talented artist, in addition to electro-acoustic music, affirmed his abilities through Byzantine modal music. Here he expressed his creative potential successfully adapting Church Slavonic text to the melodic patterns of Byzantine music. He utilized his talent for visual arts on thousands of pages of written inspirational Byzantine notation and text. About his pedagogical talent testify many students, whom he attracted and inspired with his authentic view of life and personal example.

One of the key factors that influenced Vladimir Jovanovic to initiate the renewal of Byzantine music in this-worldly circles, primarily in Belgrade, was his enthusiasm, love for the Divine through authentic devotion to the church

\footnotetext{
${ }^{22}$ Sanja (Ksenija) Bursać and Milica Rakić, students of Nikola Popmihajlov as mentioned above. York.

${ }^{23}$ Natalija Mijatović, painting professor and art department chair, Binghamton University, New
} 
Byzantine music. He created and worked in discretion and modesty in true Orthodox spirit, totally untouched by the success and acknowledgments from 'this world'. His desire was not to get glory through Byzantine music but to glorify the Lord. Vlada Jovanović, by his living example, inspired many young people who felt and recognized his sincerity and dedication as they continue to practice Byzantine music with a memory of their teacher.

\section{Translated by Tatjana Milovanović}

\section{References}

Agnì parthéne Déspoina [O, Virgin Pure] (2017, November 19). Retrieved from http://www.saint. gr/236/texts.aspx

Arsenijević, M. (prir.). (2015). Pravoslavna misionarska škola pri hramu Svetog Aleksandra Nevskog u Beogradu. Spomenica povodom tridesetogodišnjice postojanja i rada škole 19852015 [Orthodox Mission School at St. Alexander Nevsky Church in Belgrade. Testimonial for the Thirtieth School Anniversary 1985-2015]. Beograd: Pravoslavna misionarska škola pri hramu Sv. Aleksandra Nevskog u Beogradu [Belgrade: Orthodox Mission School at St. Alexander Nevsky Church in Belgrade].

Blagojević, G. (2005). O recepciji crkvene vizantijske muzike u Beogradu krajem 20. i početkom 21. veka (ili kako je Stevan Mokranjac postao stariji i srpskiji kompozitor od Stefana Srbina) [On the Reception of Church Byzantine Music in Belgrade in the Late 2oth and Early 21st Century (or How Stevan Mokranjac Became More Experienced and More Serbian Composer than Kir Stefan the Serb)]. Glasnik Etnografskog instituta SANU [The Bulletin of the Institute of Ethnography SASA], LIII, 153-171.

Blagojević, G. (2011). Ikona kao roba: jedna ilustracija pravoslavnog identiteta u Srbiji danas [Icon as a Commodity: an Illustration of Orthodox Identity in Serbia Today]. In D. Sinani (Ed.). Antropologija, religije i alternativne religije - kultura identiteta [Anthropology, Religions and Alternative Religions - Cultural Identity] (pp. 221-237). Beograd: Srpski genealoški centar i Odeljenje za etnologiju i antropologiju Filozofskog fakulteta [Belgrade: Serbian Genealogical Centre and Department of Ethnology and Anthropology, Faculty of Philosophy].

Blagojević, G. (2012). Byzantium as a Symbol and Inspiration for the Contemporary Musical Creativity in Serbia at the end of the second and the beginning of the third millennium. In I. Todorović, G. Blagojević (Eds.). Duhovna kultura i religioznost nekad i danas - različiti konteksti $i$ tradicije [Spiritual Culture and Religiousness in the Past and Now - Different Contexts and Traditions], (pp. 171-198). Beograd: Raška škola, Univerzitet u Prištini - Fakultet tehničkih nauka, Etnografski institut SANU, Centar za religijske studije IFDT-a, Narodni muzej - Čačak, Srpski naučni centar [Belgrade: Raska School, University of Pristina - Faculty of Technical Science, The SASA Institute of Ethnography, Center for Religious Studies IFDT, National Museum - Cacak, Serbian Science Center].

Blagojević, G. (2014). Vizantijsko pojanje i rodni identitet u Srbiji i Grčkoj (ženski glas između božanske ikonomije i ljudske ekonomije) [Byzantine Chants and Gender Identity in Serbia and Greece (Female Voice between the Divine Economy and Human Economy)]. In L. Radenković (Ed.). Narodna kultura Srba između Istoka i Zapada [National Culture of the Serbs between East and West], (pp. 139-156). Beograd: Balkanološki institut SANU.

Blagojević, G. (2017a). Arhimandrit Paisij (Tanasievich) Hilandarec kak pevchij: ego rol' v rasprostranenii afonskogo ifosa vizantijskogo penija v Serbii v konce 20. i nachale 21. veka [Archiman drite Pajsije (Tanasijevic) of Hilandar as a Chanter: His Role in the Expansion of the Mount Athos Way of Singing in Serbia in the late 20th and early 21st Century]. In S. Hvatova (prir.) 
Bogosluzhebnye praktiki, (pp. 39-50). Majkop: Rossijskij gumanitaryj nauchnij fond Ministerstvo obrazovanija i nauki Rossijskoj federacii FBGOU vo Adygejskij gosudarstevnnyj universitet.

Blagojević, G. (2017b). H moysikn metarrúthmish toy 1814: mia empeirikí - afhghmatologiki proséggish [Music Reform from 1814: An Empirical and Narrative Approach]. Doctoral dissertation. Athens: Library of the Department of Musicology at the Faculty of Philosophy of the National and Capodistrian University.

Blagojević, G., Pavićević, A. (2018). Od elekroakustičke muzike do vizantijskog pojanja i vice versa: Vladimir Jovanović, kompozitor [From electro-acoustic music to Byzantine chanting and vice versa: Vladimir Jovanovic, composer]. Etnoantropološki problemi, 3(2), (n.s.) [Ethnoanthropological problems 13 Vol. 2], 327-344.

Grujić. R. M. (1906). Kako se postupalo sa srpskim molbama na dvoru ćesara avstrijskog poslednje godine života patrijarha Arsenija III Čarnojevića [How Serbian Pleas Were Accepted At the Court of the Austrian Ruler in the Last Year of Life of the Patriarch Arsenije III Čarnojević]. Novi Sad: Matica srpska. Jaćimović, S. O razlikama u tradiciji crkvenog pevanja Vizantije i Srbije (2017, December 15). Retrieved from http://aperto.artf.ni.ac.rs/index. php/o-razlikama-u-tradiciji-crkvenog-pevanja-vizantije-i-srbije/

Jovanović, V. (2001) Interview: 'Nema više Marije Terezije' [No more Maria Theresa]. Iskon, 5, 22-28.

Jovanović, V. (2004). Umetnost u hrišćanstvu ili hrišćanstvo u istoriji [Art in Christianity or Christianity in History]. In J. Hercman, Vizantijska nauka o muzici [Byzantine Science of Music], (pp. 321-353). Beograd: Clio.

Jovanović, V. (2017). Antologija ili Cvetoslovlje. Svakodnevno i praznično pojanje u osam glasova [Anthology or Cvetoslovlje. Daily and Holiday Chants in Eight Voices]. Beograd: Riznica.

Jovanović, V. (2017, September 10) Život sa muzikom. Vladimir Jovanović [Life with Music. Vladimir Jovanović] Retrieved from https://www.youtube.com/watch?v=Pn17fVY3l2Y.

Jovanović, J. (2012). Identiteti izraženi kroz aktuelizaciju sviranja i gradnje kavala u Srbiji 9o-tih godina XX veka [Identity Expressed Through Playing and Making the Kaval instrument in the 199os Serbia]. Muzičke prakse Balkana: etnomuzikološke perspektive [Music Practices of the Balkans: From the Perspective of Ethnomusicology,], Dejan Despić, Jelena Jovanović, Danka Lajić-Mihajlović (prir.), (pp. 1-27). Beograd: Muzikološki institut SANU.

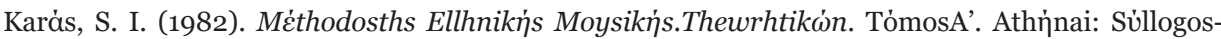
prosdiádosinthsethnikn่smoysiknjs [Karas, S. I. (1982). Method of Greek Music: Theoretikon. Vol. 1. Athens: Society for the Dissemination of National Music]

Konstantínou, G. (2014). Theoría kai práxi tis ekklisiastikís mousikís [Theory and practice of ecclesiastical music] I. M. Vatopaidíou: Áyion Óros [Vatopedi Monastery: Mount Athos].

Kovač, M. (1991). Beogradska muzička postmoderna [Belgrade Music Postmodernism]. Treći program [Radio Television of Serbia-Channel ] (90-91), 39-44.

Krstić, Danilo episkop. (1996). U početku beše smisao [In the Beginning was Meaning]. Beograd: Univerzitetski obrazovni pravoslavni bogoslovi, Hilandarski fond, zadužbina 'Nikolaj Velimirović i Justin Popović' [University Education Orthodox Theologians, The Hilandar fund, The Foundation 'Nikolaj Velimirović and Justin Popović'].

Kulišić, Š., P.Ž. Petrović, N. Pantelić. (1970). Srpski mitološki rečnik [Serbian Dictionary of Mythology]. Beograd: Nolit.

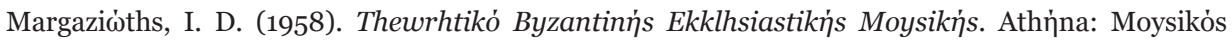
Oikos Fülippos Nákas [Margaziotis, I. D. (1958). The Theory of Byzantine Church Music. Athens. Filippos Nakas].

Mayroeidhs, M. D. (1999). Oi moysikoi trópoi sthn Anatolikí Mesógeio. Athína [Mayroeidhs, M. D. (1999). Paths of Music in the Eastern Mediterranean. Athens].

Medić, I. (2007). The Ideology of Moderated Modernism in Serbian Music and Musicology [The Ideology of Moderated Modernism in Serbian Music and Musicology], Muzikologija 7, 279-294. 
Milojković, M. (2017). Pilgrimage through a sound horizon - a guide through the electroacoustic works by Vladimir Jovanović (1956-2016), New Sound, 49, I, 79-96.

Mitrović, T. (2014). Hipervizantijski paradoks: Zašto je moguće/potrebno govoriti o stilu savremenog crkvenog slikarstva u Srbiji? [The Hyperbyzantine Paradox: Why is it Possible and Necessary to Analyse the Stylistic Aspects of Contemporary Serbian Church Painting?] Religija, religioznost $i$ savremena kultura. Od mističnog do (i)racionalnog i vice versa, Zbornik Etnografskog instituta SANU [Religion, Religiousness and Contemporary Culture. From Mystical to (Ir)Rational and Vice Versa, The Bulletin of the Institute of Ethnography SASA] 30, 87-103.

Molitva pre i posle pojanja [Prayer Before and After Chanting] (2018, January 10). Retrieved fromhttps://www.molitvenik.in.rs/molitve/molitve_u_raznim_prilikama/molitva_pre_i_posle_ pojanja.html

Nektarioymonachov́iropsáltoy. (1931). Moysikósthhsayrósths Leitoyrgias. Tómosprótoskaideúteros. 'Agion 'Oros. [Nektarioy monachoy ieropsaltoy. (1931). The Musical Treasure of the Liturgy. Vol. 1 and 2. Mount Athos.]

Perković Radak, I. (2008). Od anđeoskog pojanja do horske umetnosti. Srpska horska crkvena muzika u periodu romantizma (do 1914. godine) [From Angelic Singing to Choral Art. Serbian Choral Church Music of the Romanticism period (till 1914)]. Faculty of Music Arts, Musicological studies - dissertations, 1. Belgrade.

Rajković-Petronijević, Lj. (1978). Stara srpska muzika u periodu od IX do XV veka [Old Serbian Music between the 4th and the 15th century]. Teološki pogledi, XI (4), 245-257.

Romanou, K. G. (1973) Great Theory of Music by Chrysanthos of Madytos. (K. G. Romanou, Trans.). MAThesis. Indiana University.

Rwmanov่, K. (1985) H metarrùthmish toy 1814. Moysikologia, 1, 7-22. [Romanou, K. (1985) Music Reform from 1814. Musicology, 1, 7-22.]

Romanou, K. (2010) Introduction. In Great Theory of Music by Chrysanthos of Madythos. (K. Romanou, Trans). New York: The Axion Estin Foundation. New Rochelle.

Savremena srpska muzika - Vladimir Jovanović [Contemporary Serbian Music - Vladimir Jovanović]. (2016, September 6). Retrieved from http://www.rts.rs/page/radio/sr/story/1466/radio-beograd-3/2439970/savremena-srpska-muzika--vladimir-jovanovic.html

Státhhs, G. (2016). Ta prwtógrafa ths exhgýsews eis thn Néan Méthodon shmeiografias, tómos A' . Athinna: 'Idryma Byzentinìs Moysikologias [Stathis, G. (2016). The Initial Interpretations of the New Method Notation Simiography. Vol. 1. Athens: Byzantine Musicology Foundation].

Stefanović, D. (1961a). Izgoreli neumski rukopis br. 93 Narodne biblioteke - jedini poznati muzički spomenik iz srpskog srednjeg veka [Neume Music Manuscript No. 93 from the National Library lost in fire - the only known musical monument from the Middle Ages in Serbia]. Bibliotekar, XIII, $5,379-384$.

Stefanović, D. (1961b). Nekoliko podataka o grčkom uticaju na srpsko crkveno pojanje [Some information about the Greek influence on Serbian church chanting]. Bogoslovlje 1-2, 107-111.

Stefanović, D. (1961c). The Earliest Dated and Notated Document of Serbian Chant, Zbornik radova Vizantološkog instituta [Compendium of the Byzanthological Institute], 7, Beograd, 187-196.

Stefanović, D. (prir.) (1975). Stara srpska muzika - primeri crkvenih pesama iz XV veka [Old Serbian Music - Examples of the 15th Century Church Songs], posebna izdanja [special editions], 15/I. Beograd: Muzikološki institut SANU

Stefanović, D. (1994). Crkveno pojanje i crkvena muzika [Church Chants and Church Music].Zbornik Matice srpske za scenske umetnosti i muziku [Matica Srpska Journal of Performing Arts and Music], 15, 23-31. 